\title{
Microwave Irradiation Synthesis of Various Substituted Chalcones Using Various Heterogeneous Catalysts under Solvent - Free Conditions and their Biological Studies
}

\author{
SHWETA SHOREY ${ }^{\mathrm{a}}$, PRAKASH C. CHOUDHARY ${ }^{\mathrm{b}}$ and KUMUD INTODIA ${ }^{\mathrm{a}^{*}}$ \\ ${ }^{\mathrm{a}}$ Department of Chemistry, S M B Govt. P.G. College Nathdwara \\ M.L. Sukhadia University, Udaipur (Raj)-313001, India \\ ${ }^{\mathrm{b}}$ Department of Chemistry, University College of Science, M. L. Sukhadia University \\ Udaipur (Raj)-313001, India \\ sshorey2k8@gmail.com
}

Received 20 July 2012 / Accepted 16 August 2012

\begin{abstract}
Synthesis of eight substituted chalcones using various heterogeneous catalysts such as Mont- K10, anhydrous $\mathrm{K}_{2} \mathrm{CO}_{3}$, anhydrous $\mathrm{ZnCl}_{2}$ and fused $\mathrm{Ba}(\mathrm{OH})_{2}$ under MWI was carried out to improved Claisen -Schmidt condensation reaction. A comparative aspect of different compounds in respect of different catalysts, time taken and per cent yield has been discussed. The advantages of this process is to design and develop new synthetic routes to various bioactive chalcone which is environmentally desirable and economically viable. The structures of all the compounds have been established by analytical and spectral (IR, ${ }^{1} \mathrm{H}$ NMR, \& mass) data. The synthesized compounds were also used for various biological screening.
\end{abstract}

Keywords: Chalcone, Synthesis, Heterogeneous catalyst, Biological evaluation

\section{Introduction}

The chalcones are $\alpha, \beta$-unsaturated ketones containing the reactive ketoethylenic group CO$\mathrm{CH}=\mathrm{CH}$-. Presence of $\alpha, \beta$-unsaturated carbonyl system in chalcone makes it biologically active. Chalcones have been used as intermediate for the preparations of compounds having therapeutic value. Literature review reveals that chalcone derivatives exhibits diverse pharmacological activities such as anti-AIDS ${ }^{1}$, anti-inflammatory ${ }^{2}$, anticancer ${ }^{3}$, antitubercular ${ }^{4}$, antibacterial $^{5}$, antioxidant ${ }^{6}$, antimalarial ${ }^{7}$ and antileishmanial ${ }^{8}$ activity.

They are commonly synthesized via the Claisen-Schmidt condensation between acetophenone and benzaldehyde. This reaction is catalyzed by acids and bases under homogeneous conditions. This homogenous reaction gives low yield, takes longer reaction time and presents several hurdles, such as catalysts recovery and waste disposal problems. In this respect, heterogeneous catalysts are considered as an eco-friendly alternative. The utilization of heterogeneous catalysts for the production of chalcones was reported in the 
literature ${ }^{9-12}$. Utilization of greener process i.e. non-conventional energy source like microwave ${ }^{13}$ has become a very popular and useful technique in synthetic organic chemistry and has gained wide popularity due to many practical advantages associated with enhanced reaction rates, high yields, improved selectivity and environment friendly reaction conditions. Further studies on the efficient synthesis of chalcones are of current interest because of their wide range of applications. Keeping in view the biological importance of 3 -nitrochalcones as antileishmanial agents ${ }^{14}$ and our ongoing endeavors in the development of environmentally benign protocols related to chalcones ${ }^{15}$ we now report facile nonconventional heterogeneous approach for the synthesis of substituted chalcones with a wide range of groups of varying lipophilicities and electronic character from substituted acetophenones and benzaldehydes using basic solid supports (Mont-K10, anhydrous $\mathrm{K}_{2} \mathrm{CO}_{3}$, anhydrous $\mathrm{ZnCl}_{2}$ and fused $\mathrm{Ba}(\mathrm{OH})_{2}$ ) under microwave activation. For comparison the results under conventional method are also presented. The antimicrobial activity of some representative members have been discussed.

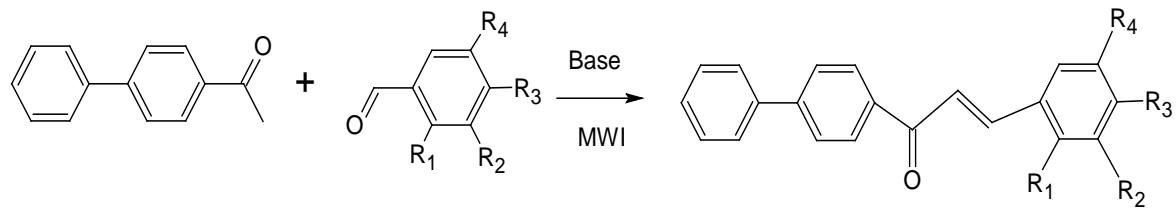

1

\begin{tabular}{ccccc} 
& \multicolumn{3}{c}{ Scheme 1 } & \\
\hline Compd.No. & $\mathrm{R}_{1}$ & $\mathrm{R}_{2}$ & $\mathrm{R}_{3}$ & $\mathrm{R}_{4}$ \\
\hline 3a & $\mathrm{H}$ & $\mathrm{H}$ & $\mathrm{H}$ & $\mathrm{H}$ \\
3b & $\mathrm{H}$ & $\mathrm{H}$ & $\mathrm{OCH}_{3}$ & $\mathrm{H}$ \\
3c & $\mathrm{H}$ & $\mathrm{OCH}_{3}$ & $\mathrm{OCH}_{3}$ & $\mathrm{H}$ \\
3d & $\mathrm{H}$ & $\mathrm{OCH}_{3}$ & $\mathrm{OCH}_{3}$ & $\mathrm{OCH}_{3}$ \\
3e & $\mathrm{Cl}$ & $\mathrm{H}$ & $\mathrm{Cl}$ & $\mathrm{H}$ \\
3f & $\mathrm{H}$ & $\mathrm{H}$ & $\mathrm{Br}$ & $\mathrm{H}$ \\
3g & $\mathrm{H}$ & $\mathrm{NO}_{2}$ & $\mathrm{H}$ & $\mathrm{H}$ \\
3h & $\mathrm{H}$ & $\mathrm{H}$ & $\mathrm{N}\left(\mathrm{CH}_{3}\right)_{2}$ & $\mathrm{H}$ \\
\hline
\end{tabular}

\section{Experimental}

Reagents and solvents were from commercial suppliers (Sigma-Aldrich, CDH, Thomas-Baker etc.) and used as provided, unless indicated otherwise. Solvents were analytical grade and were stored over molecular sieves $\left(4 \mathrm{~A}^{\circ}\right)$. Reactions were carried out in oven-dried glassware. Melting points were determined in open glass capillaries and are uncorrected. IR spectra were recorded on Perkin-Elmer spectrum GX spectrophotometer on $\mathrm{KBr}$ plate. ${ }^{1} \mathrm{H}$ NMR spectra were recorded by using Bruker F $113 \mathrm{~V}\left(400 \mathrm{MHz}\right.$ ) with $\mathrm{CDCl}_{3} / \mathrm{DMSO}-\mathrm{d}_{6}$ as solvent \& TMS as internal reference. Chemical shifts are expressed in $\delta \mathrm{ppm}$. Mass spectral analysis was carried out on Shimadzu GCMS-QP2010 spectrometer. Experiments were performed using Kenstar Microwave Oven with microwave energy output 900 W \& frequency $2450 \mathrm{MHz}$.

\section{General procedure for the synthesis of chalcones (3a-h)}

\section{Method A- Conventional}

To a solution of biphenyl acetophenone $\mathbf{1}(0.01 \mathrm{~mole})$ and substituted aromatic aldehyde 2 (0.01 mole) dissolved in ethanol / methanol (10 mL) was added basic inorganic catalysts (40-400 mg). 
The heterogeneous mixture was stirred at room temperature for 24-36 h. After the completion of the reaction as monitored by TLC, the reaction mixture was treated with ice-cold water / dilute acid to get the precipitate of the product leaving behind Mont-K10/ fused $\mathrm{Ba}(\mathrm{OH})_{2}$ dissolved in solution. The product was filtered, washed with water and recrystallized with ethanol or ethanol-benzene mixture $(1: 1 ; \mathrm{v} / \mathrm{v})$ to afford analytical samples of chalcones 3.

Method B: - Solid phase microwave irradiation (MWI)

To a solution of biphenyl acetophenone 1 (0.01 mole) and substituted aromatic aldehyde 2 (0.01mole) in ethanol $(5 \mathrm{~mL})$ taken in a borosil flask $(100 \mathrm{~mL})$, inorganic catalysts $(5-7 \mathrm{~g})$ was added. The reaction mixture was mixed and the adsorbed material was dried, in air and irradiated inside the microwave oven and irradiated intermittently for a period as specified in Table 1. Progress of the reaction was monitored by TLC. After the completion of the reaction, the product was cooled, purified and recrystallized using similar procedure as mentioned in method A.

\section{Spectral data of synthesized compounds (3a-h)}

(2E)-1-(biphenyl-4-yl)-3-phenylprop-2-en-1-one (3a)

Yellow; IR ( $\left.\boldsymbol{\vartheta}_{\max }, \mathrm{KBr}\right) ; 1680(\mathrm{C}=\mathrm{O}), 1006\left(\mathrm{CH}=\mathrm{CH}\right.$ trans) $\mathrm{cm}^{-1} ;{ }^{1} \mathrm{H}$ NMR $\left(\mathrm{CDCl}_{3}\right) \delta ; 7.28-$ 8.08(14H,m,Ar-H),8.07(1H,d,H- $\alpha), 7.73(1 \mathrm{H}, \mathrm{d}, \mathrm{H}-\beta)$; EI-MS; m/z $284\left(\mathrm{M}^{+}\right)$.

(2E)-1-(biphenyl-4-yl)-3-(4-methoxyphenyl)prop-2-en-1-one (3b)

Cream; IR ( $\left.\vartheta_{\max }, \mathrm{KBr}\right) ; 1654(\mathrm{C}=\mathrm{O}), 1035\left(\mathrm{CH}=\mathrm{CH}\right.$ trans) $\mathrm{cm}^{-1} ;{ }^{1} \mathrm{H}$ NMR $\left(\mathrm{CDCl}_{3}\right) \delta ; 7.11-$ 7.95(13H,m,Ar-H),7.15(1H,d,H- $\alpha), 7.87(1 \mathrm{H}, \mathrm{d}, \mathrm{H}-\beta), 3.86\left(3 \mathrm{H}, \mathrm{s}, \mathrm{OCH}_{3}\right)$; EI-MS; m/z $314\left(\mathrm{M}^{+}\right)$.

(2E)-1-(biphenyl-4-yl)-3-(3,4-dimethoxyphenyl)prop-2-en-1-one (3c)

Yellow; IR ( $\left.\boldsymbol{\vartheta}_{\max }, \mathrm{KBr}\right) ; 1685(\mathrm{C}=\mathrm{O}), 1019(\mathrm{CH}=\mathrm{CH}$ trans $) \mathrm{cm}^{-1} ;{ }^{1} \mathrm{H}$ NMR $\left(\mathrm{CDCl}_{3}\right) \delta ; 7.21-$ 7.75(12H,m,Ar-H),6.95(1H,d,H- $\alpha), 7.47(1 \mathrm{H}, \mathrm{d}, \mathrm{H}-\beta), 3.97\left(6 \mathrm{H}, \mathrm{s}, \mathrm{OCH}_{3}\right)$; EI-MS; m/z $344\left(\mathrm{M}^{+}\right)$.

(2E)-1-(biphenyl-4-yl)-3-(3,4,5-trimethoxyphenyl)prop-2-en-1-one (3d)

Yellow; IR ( $\left.\cup_{\max }, \mathrm{KBr}\right) ; 1680(\mathrm{C}=\mathrm{O}), 1005\left(\mathrm{CH}=\mathrm{CH}\right.$ trans) $\mathrm{cm}^{-1} ;{ }^{1} \mathrm{H}$ NMR $\left(\mathrm{CDCl}_{3}\right) \delta ; 7.07-$ 7.59(11H,m,Ar-H),8.14(1H,d,H- $\alpha), 7.84(1 \mathrm{H}, \mathrm{d}, \mathrm{H}-\beta), 3.83\left(9 \mathrm{H}, \mathrm{s}, \mathrm{OCH}_{3}\right)$; EI-MS; m/z $374\left(\mathrm{M}^{+}\right)$.

(2E)-1-(biphenyl-4-yl)-3-(2,4-dichlorphenyl)prop-2-en-1-one (3e)

Yellow; IR ( $\left.\cup_{\max }, \mathrm{KBr}\right) ; 1681(\mathrm{C}=\mathrm{O}), 1005\left(\mathrm{CH}=\mathrm{CH}\right.$ trans) $\mathrm{cm}^{-1} ;{ }^{1} \mathrm{H}$ NMR $\left(\mathrm{CDCl}_{3}\right) \delta ; 7.20-$ 7.58(12H,m,Ar-H),8.27(1H,d,H- $\alpha), 7.53(1 \mathrm{H}, \mathrm{d}, \mathrm{H}-\beta)$; EI-MS; $\mathrm{m} / \mathrm{z} 353\left(\mathrm{M}^{+}\right)$.

(2E)-1-(biphenyl-4-yl)-3-(4-bromophenyl)prop-2-en-1-one (3f)

Light yellow; IR ( $\left.\boldsymbol{\vartheta}_{\max }, \mathrm{KBr}\right) ; 1662(\mathrm{C}=\mathrm{O}), 1091\left(\mathrm{CH}=\mathrm{CH}\right.$ trans) $\mathrm{cm}^{-1} ;{ }^{1} \mathrm{H}$ NMR $\left(\mathrm{CDCl}_{3}\right)$ $\delta$; 7.16-7.53(9H,m,Ar-H),7.74(1H,d,H- $\alpha), 8.03(1 \mathrm{H}, \mathrm{d}, \mathrm{H}-\beta), 7.04(2 \mathrm{H}, \mathrm{d}, \mathrm{J}=8 \mathrm{MHz}, \mathrm{Ar}-\mathrm{H}), \quad 6.85$ (2H,d,J=8.4MHz,Ar-H); EI-MS; m/z $284\left(\mathrm{M}^{+}\right)$.

(2E)-1-(biphenyl-4-yl)-3-(3-nitrophenyl)prop-2-en-1-one (3g)

Yellow; IR ( $\left.\bullet_{\max }, \mathrm{KBr}\right) ; 1683(\mathrm{C}=\mathrm{O}), 1006\left(\mathrm{CH}=\mathrm{CH}\right.$ trans) $\mathrm{cm}^{-1} ;{ }^{1} \mathrm{H}$ NMR $\left(\mathrm{CDCl}_{3}\right) \delta ; 7.35-$ 8.40(13H,m,Ar-H),7.82(1H,d,H- $\alpha), 8.34(1 \mathrm{H}, \mathrm{d}, \mathrm{H}-\beta)$; EI-MS; m/z $329\left(\mathrm{M}^{+}\right)$.

(2E)-1-(biphenyl-4-yl)-3-[4-(dimethylamino)phenyl]prop-2-en-1-one (3h)

IR $\left(\cup_{\max }, \mathrm{KBr}\right) ; 1680(\mathrm{C}=\mathrm{O}), 1020(\mathrm{CH}=\mathrm{CH}$ trans $) \mathrm{cm}^{-1} ;{ }^{1} \mathrm{H}$ NMR $\left(\mathrm{CDCl}_{3}\right) \delta ; 7.12-7.84$ (9H,m,Ar-H),7.71(1H,d,H- $\alpha), 7.84(1 \mathrm{H}, \mathrm{d}, \mathrm{H}-\beta), 6.26(2 \mathrm{H}, \mathrm{d}, \mathrm{J}=8.8 \mathrm{MHz}, \mathrm{Ar}-\mathrm{H}), 7.22(2 \mathrm{H}, \mathrm{d}, \mathrm{J}=8 \mathrm{MHz}$, Ar-H); EI-MS; m/z $327\left(\mathrm{M}^{+}\right)$. 


\section{Results and Discussion}

\section{Comparative profile of synthesis}

The reaction of biphenyl acetophenones (1) and substituted aromatic aldehyde (2) on a solid inorganic support using either anhyd. $\mathrm{K}_{2} \mathrm{CO}_{3}$, fused $\mathrm{Ba}(\mathrm{OH})_{2}$, Mont-K10 and anhydrous $\mathrm{ZnCl}_{2}$ under microwave irradiation afforded chalcones 3a-h (Scheme 1). This is a modified Claisen-Schmidt condensation. In the absence of MWI the condensation reaction of acetophenones (1) and benzaldehyde (2) did not take place by conventional method in the presence of anhydrous $\mathrm{K}_{2} \mathrm{CO}_{3}$ and anhydrous $\mathrm{ZnCl}_{2}$. However, the reactions were perfectly performed under microwave irradiation (MWI) with a yield as high as $85 \%$ and $90 \%$ respectively. Because the basicity of anhydrous $\mathrm{K}_{2} \mathrm{CO}_{3}$ and anhydrous $\mathrm{ZnCl}_{2}$ is too weak to catalyze the reaction at conventional conditions, MWI can enhance conspicuously reaction selectivity and activity. The reactions were also carried out in presence of other base catalysts such as fused $\mathrm{Ba}(\mathrm{OH})_{2}$ and Mont-K10 resulting 1,3diarylpropenones (3) with different yields as shown in Table 1.

Table 1. Experimental data of compounds (3a-h). A comparison of reaction time and yields of compounds (3a-h) under different catalysts

\begin{tabular}{|c|c|c|c|c|c|c|c|c|c|c|}
\hline \multirow[b]{2}{*}{$\begin{array}{l}\text { Compd. } \\
\text { No. }\end{array}$} & \multirow[b]{2}{*}{$\begin{array}{l}\text { Mol.formula } \\
\text { (Mol.weight) }\end{array}$} & \multirow[b]{2}{*}{ 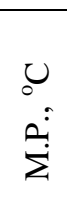 } & \multicolumn{4}{|c|}{ Reaction time, minutes } & \multicolumn{4}{|c|}{ Percent yield } \\
\hline & & & $\begin{array}{l}0 \\
1 \\
\stackrel{1}{0} \\
\stackrel{0}{\Sigma}\end{array}$ & 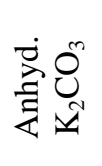 & 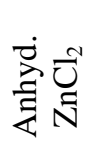 & 吢 & $\begin{array}{l}0 \\
\vec{y} \\
\stackrel{1}{ \pm} \\
\dot{0} \\
\dot{z}\end{array}$ & 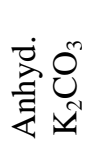 & 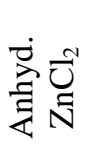 & 志 \\
\hline 3a & $\mathrm{C}_{21} \mathrm{H}_{16} \mathrm{O}(284.12)$ & 100 & 8 & 8 & 13 & 5 & 79 & 60 & 50 & 70 \\
\hline $3 \mathbf{b}$ & $\mathrm{C}_{22} \mathrm{H}_{18} \mathrm{O}_{2}(314.13)$ & 90 & 5 & 10 & 12 & 5 & 88 & 62 & 46 & 75 \\
\hline 3c & $\mathrm{C}_{23} \mathrm{H}_{20} \mathrm{O}_{3}(344.14)$ & 110 & 10 & 9 & 11 & 10 & 82 & 61 & 48 & 80 \\
\hline 3d & $\mathrm{C}_{24} \mathrm{H}_{22} \mathrm{O}_{4}(374.15)$ & 95 & 6 & 7 & 15 & 4 & 92 & 63 & 52 & 70 \\
\hline $3 \mathbf{e}$ & $\mathrm{C}_{21} \mathrm{H}_{14} \mathrm{CI}_{2} \mathrm{O}(353.24)$ & 105 & 5 & 9 & 15 & 2 & 90 & 60 & 50 & 73 \\
\hline $3 f$ & $\mathrm{C}_{21} \mathrm{H}_{15} \mathrm{BrO}(363.24)$ & 125 & 6 & 8 & 8 & 2 & 78 & 62 & 45 & 75 \\
\hline $3 g$ & $\mathrm{C}_{21} \mathrm{H}_{15} \mathrm{NO}_{3}(329.34)$ & 75 & 5 & 10 & 8 & 6 & 80 & 65 & 53 & 71 \\
\hline $3 \mathbf{h}$ & $\mathrm{C}_{23} \mathrm{H}_{21} \mathrm{NO}(327.41)$ & 120 & 5 & 9 & 12 & 5 & 84 & 60 & 47 & 81 \\
\hline
\end{tabular}

The synthesis of chalcones 3a-h under MWI using Mont-K10 or fused $\mathrm{Ba}(\mathrm{OH})_{2}$ required generally less time with improved yield for completing the reaction in comparison to anhydrous $\mathrm{ZnCl}_{2}$. Compound 3e having 4'- $\mathrm{Cl}$ and $\mathbf{3 b}$ having 4'- $\mathrm{OCH}_{3}$ substituents were obtained within 10-15 minutes in $~ 90 \%$ yield in presence of used base inorganic catalysts (Table 1). The use of anhyd. $\mathrm{K}_{2} \mathrm{CO}_{3}$ or fused $\mathrm{Ba}(\mathrm{OH})_{2}$ as an inorganic solid support not only eliminates the use of external expensive and hazardous bases for catalyzing the reaction but also avoids the use of organic solvents for elution. The products got precipitated after acidification leaving behind $\mathrm{K}_{2} \mathrm{CO}_{3}$ and $\mathrm{Ba}(\mathrm{OH})_{2}$ in solution. Only a limited amount of $\mathrm{EtOH} / \mathrm{MeOH}$ was used for adsorbing the reactants on the solid support anhydrous $\mathrm{K}_{2} \mathrm{CO}_{3}$ and fused $\mathrm{Ba}(\mathrm{OH})_{2}$. Microwave and ultrasound mediated synthesis of chalcones have been proved efficient in terms of reaction time, yield and elimination of organic solvents and external hazardous bases. The use of anhydrous $\mathrm{ZnCl}_{2}$ to catalyze the reaction resulted low product purity and yield (Table 1) in comparison to other catalysts. Although anhydrous $\mathrm{ZnCl}_{2}$ can be reused for multiple using, however, purification of crude catalysts requires large amount of solvent after finishing the reaction. 
From the results it can be deduced that the yields are in general higher under MWI in comparison to conventional method and Mont-K10 was the best choice in all cases with the advantages of convenient operation, high yield and product purity. Secondary reactions such as Cannizzaro of aldehydes, aldol condensation of aldehydes and ketones was not observed.

The structures of all the synthesized compounds were established on the basis of their spectral data. In the IR spectra the chalcones had absorption around 1697-1650 $\mathrm{cm}^{-1}$ and near $1000 \mathrm{~cm}^{-1}$ indicative of the conjugated carbonyl and $-\mathrm{CH}=\mathrm{CH}$ - out of plane trans- vibrations. The $\mathrm{C}=\mathrm{C}$ bond absorptions were seen around $1636-1503 \mathrm{~cm}^{-1}$. The ${ }^{1} \mathrm{H}$ NMR doublets at $\delta$ 7.65-7.0 and $\delta$ 8.2-7.5 with coupling constant values of $\sim 15 \mathrm{~Hz}$ indicated the presence of two ethylenic hydrogens $\mathrm{H}-\alpha$ and $\mathrm{H}-\beta$ respectively as $\mathrm{AB}$ pattern in the E-configuration. The chemical shift of $\mathrm{H} \alpha$ protons are of higher field then those of $\mathrm{H} \beta$ protons in all chalcones. This may possibly due to the polarization of $\mathrm{C}=\mathrm{C}$ double bond in the system being predominantly caused by the carbonyl group so as to make electron density greatest at the $\alpha$-position than that of $\beta$-position.

\section{Antimicrobial evaluation}

The antimicrobial activity was determined using cup plate agar diffusion method by measuring the zone of inhibition in $\mathrm{mm}$. All the newly synthesized compounds (3a-h) were screened in vitro for their antibacterial activity against five bacteria viz. B.subtilis, K.pneumoniae, E.coli, P.aureoginosa and S.aures at a concentration of $500 \mu \mathrm{g} / \mathrm{mL}$. Antifungal activity was tested against Candida albicans and Aspergillus fumigates at a concentration of $500 \mu \mathrm{g} / \mathrm{mL}$. Ciprofloxacin (10 $\mu \mathrm{g} /$ disc) was used as a standard drug for antibacterial screening and fluconazole (10 $\mu \mathrm{g} /$ disc) was used as a standard for antifungal screening.

Table 2. Antimicrobial activity of the synthesized compounds (3a-h) Zone of inhibition (mm)

\begin{tabular}{|c|c|c|c|c|c|c|c|}
\hline \multirow{2}{*}{$\begin{array}{l}\dot{0} \\
\dot{z} \\
\dot{0} \\
\dot{0}\end{array}$} & \multicolumn{5}{|c|}{ Antimicrobial activity } & \multicolumn{2}{|c|}{ Antifungal activity } \\
\hline & B.subtilis & P.aereoginosa & S.aures & E.coli & K.pneumoniae & A.fumigatus & C.albicane \\
\hline $3 \mathbf{a}$ & 17 & 22 & 16 & 15 & 18 & 16 & 15 \\
\hline $3 b$ & 19 & 24 & 18 & 17 & 17 & 17 & 13 \\
\hline 3c & 22 & - & 12 & 14 & 18 & 20 & 19 \\
\hline 3d & 16 & 24 & - & 20 & 16 & 16 & 14 \\
\hline $3 \mathbf{e}$ & 20 & 22 & 10 & 15 & 20 & 22 & 24 \\
\hline $3 f$ & 18 & - & 13 & 18 & 22 & 20 & 21 \\
\hline $3 g$ & 16 & 26 & - & 19 & 16 & 18 & 13 \\
\hline $3 h$ & 14 & 25 & - & 21 & 13 & 18 & 16 \\
\hline $\mathrm{C}_{1}$ & 35 & 40 & 16 & 37 & 36 & 30 & 30 \\
\hline $\mathrm{C}_{2}$ & - & - & 16 & 18 & - & - & - \\
\hline
\end{tabular}

Standard drug for antibacterial activity for $\mathbf{3 b}, \mathbf{3 d} \mathbf{3} \mathbf{3} \mathbf{g}$ and $\mathbf{3 h}$ are ciprofloxacin $\left(\mathrm{C}_{1}\right)$, for compounds $\mathbf{3 c}$, $\mathbf{3 e}$ and $\mathbf{3 f}$ are gatifloxacin $\left(\mathrm{C}_{2}\right)$ and for antifungal activity are flucanazole $\left(\mathrm{C}_{1}\right)$. Chalcones having methoxy group (3b, $\mathbf{3 c}$ and $\left.\mathbf{3 d}\right)$, chloro, bromo (3e, $\mathbf{3 f}$ ), nitro group (3g) and dimethyl amino group (3h) showed activity against the tested microorganisms. Compounds 3h having (3,4-OMe) group and $\mathbf{3 k}$ having $2,4-\mathrm{Cl}_{2}$ showed moderate activity against S.aureus and E.coli, whereas the activity of compound $3 f$ having 4-Br group showed good activity against E.coli. 


\section{Conclusion}

In conclusion the synthesis of chalcones by Claisen-Schmidt condensation was performed in milder conditions by using microwaves irradiation in presence of anhy $\mathrm{K}_{2} \mathrm{CO}_{3}$, fused $\mathrm{Ba}(\mathrm{OH})_{2}$, Mont-K10 and anhydrous $\mathrm{ZnCl}_{2}$. This green methodology is very efficient, simple, high yielding and purity with shorter reaction period and easier work up compared with previous methods in the literature. The methods can compete with the traditionally used $\mathrm{NaOH} / \mathrm{KOH}$ as an alternative method for the production of differently substituted chalcones having electron donating and electron withdrawing groups and in general for the production of the fine chemicals due to the mild conditions. From the results Mont-K10 was found most efficient in comparison to other base catalysts.

\section{Acknowledgment}

The authors are thankful to Shri B. L.Verma, Rtd. Professor Department of Chemistry, University College of Science, M.L. Sukhadia University- Udaipur (Raj) for their kind cooperation and UGC Bhopal for financial support.

\section{References}

1. Wu J H, Wang X H, Yi Y H and Lee K H, Bioorg Med Chem Lett., 2003, 13(10), 1813.

2. Won S J, Liu C T, Tsao L T, Weng J R, Ko H H, Wang J P and Lin C N, Eur J Med Chem., 2005, 40, 103-112.

3. Sabzevari O, Galati G, Moridani M Y, Siraki A and O’Brien P J, Chem Biol Interact., 2004, 148, 57-67.

4. Sivakumar P M, Seenivasan S P, Kumar V and Doble M, Bioorg Med Chem Lett., 2007, 17(6), 1695.

5. Poppano N B, De-Centorbi O P, Debattist N B, De-Milan C C, Browkowski E J and Feretti F H, Rev Argent Microbiol., 1985, 17, 27; Chem Abstr., 1986, 104, 183206.

6. Cioffi G, Escobar L M, Braca A and De-Tommasi N, J Nat Prod., 2003, 66, 1061.

7. Chen M, Christensen S B, Zhai L, Rasmussen M H, Theander T G, Frokjaer S, Steffensen B, Davidson J and Kharazmi A, J Infect Dis., 1997, 176, 1327.

8. Nielsen S F, Christensen S B, Cruciani G, Kharazmi A and Liljefors T, J Med Chem., 1998, 41, 4819-4832.

9. Shaabani A, Bazgir A, Teimouri F and Lee D G, Tetrahedron Lett., 2002, 43, 5165.

10. Kidwai M, Sapra P, Misra P, Saxena R K and Singh M, Bioorg Med Chem., 2001, 9, 217.

11. Wei W, Qunrong W, Liqin D, Aiqing Z and Duoyuan W, Ultrasonics Sonochem., 2005, 12, 411-414.

12. Perozo-Rondon E, Martin-Aranda R M, Casal B, Duran-Valle C J, Lau W N, Zhang X F and Yeung K L, Catalysis Today, 2006, 114(2-3), 183-187.

13. Varma R S, Tetrahedron, 2002, 58, 1235.

14. Boeck P, Bandeira Falco C A, Leal P C, Yunes R A, Filho V C, Torres-Santos E C and Rossi- Bergmann B, Bioorg Med Chem., 2006, 14(5), 1538-1545.

15. (a.) Jhala Y S, Dulawat S S and Verma B L, Indian J Chem., 2006, 45B, 466-469; (b) Jhala Y S, Gahlot U S, Dulawat S S and Verma B L, Heterocycl Commun., 2006, 12(3-4), 253; (с.) Gahlot U S, Rao S S, Jhala Y S, Dulawat S S, Ameta K L and Verma B L, Afinidad, 2003, 60(508), 558; (d) Rao S S, Gahlot U S, Dulawat S S, Vyas R, Ameta K L and Verma B L, Afinidad, 2003, 60(505), 271; (e) Vyas R, Choudhary P C, Sharma H and Verma B L, Indian J Heterocycl Chem., 2008, 17, 237. 